\title{
Mechanical Properties and the Microstructure of $\mathrm{Al}_{2} \mathrm{O}_{3} / \mathrm{Al} / \mathrm{Al}_{2} \mathrm{O}_{3}$ Joints with the Surface Modification of Alumina by a Thin Layer of $\mathrm{Ti}+\mathrm{Nb}$
}

\author{
Marzanna Ksiazek, Adam Tchorz, and Lukasz Boron
}

\author{
(Submitted November 19, 2013; in revised form March 18, 2014; published online April 18, 2014)
}

\begin{abstract}
$\mathrm{Al}_{2} \mathrm{O}_{3} / \mathrm{Al} / \mathrm{Al}_{2} \mathrm{O}_{3}$ joints were formed by liquid-state bonding of alumina substrates covered with a thin $\mathrm{Ti}+\mathrm{Nb}$ coating of $900 \mathrm{~nm}$ thickness with the use of an $\mathrm{Al}$ interlayer of $30 \mu \mathrm{m}$ at $973 \mathrm{~K}$ under a vacuum of $0.2 \mathrm{mPa}$ for $5 \mathrm{~min}$. The bond strength of the joints was examined by a four-point bending test at 295, 373, and $473 \mathrm{~K}$. Optical, scanning, and transmission electron microscopies were applied for detailed characterization of the interface structure and failure characteristics of fractured joint surfaces. The analysis of the results has shown that (i) bonding occurred due to the formation of a reactive interface on the metal side of the joint in the presence of $\mathrm{Al}_{3} \mathrm{Nb}(\mathrm{Ti})$ precipitates and (ii) modification of $\mathrm{Al}_{2} \mathrm{O}_{3}$ by a thin layer of $\mathrm{Ti}+\mathrm{Nb}$ increases the hardness at the interface and makes it possible to achieve reliable joints working at elevated temperatures.
\end{abstract}

Keywords coatings, joining, surface engineering

\section{Introduction}

The metal/ceramic joint showed a series of unique properties that do not occur in any other material in such a combination. The applicability and occupied time of the final metal/ceramic joints depend on the dissipation of the stress concentration, which increases the ceramic's cracking strength in the formation of such interatomic bonds that will ensure obtaining a durable and reliable joint. The reliability of this joint depends on the interfacial properties between the metal and ceramic, e.g., adhesion properties and thermal stability. However, the differences in physical and chemical characteristics between the metal and ceramics cause severe changes in the region of the interface (a discontinuous change in the elastic, plastic, and thermal characteristics at the interface), and the difference between the values of linear coefficients of the thermal expansion of the metal and ceramic leads to the formation of residual stress at the interface. That is why in order to identify the optimum mechanical integrity of the metal/ ceramic joint, one shall consider a number of factors: the process of the bond formation, chemical composition, morphology and the structure of the metal/ceramic joint, thermal area and plastic

This article is an invited submission to JMEP selected from presentations at the Symposia "Wetting," "Interface Design," and "Joining Technologies" belonging to the Topic "Joining and Interface Design" at the European Congress and Exhibition on Advanced Materials and Processes (EUROMAT 2013), held on September 8-13, 2013, in Sevilla, Spain, and has been expanded from the original presentation

Marzanna Ksiazek, Adam Tchorz, and Lukasz Boron, Foundry Research Institute, Zakopiańska 73, 30-418 Kraków, Polska. Contact e-mail: marzanna.ksiazek@iod.krakow.pl. incompatibility, the limit value of the metal strength and its thickness (it determines the distribution of residual stress and the stress occurring currently at the joint load), the number of defects in a ceramic material and at the interface, and also the resistance of the interfacial region to cracking (it determines the course of the cracking path) (Ref 1-4).

The phenomena occurring at the contact of liquid and solid phase have a decisive influence on the process of joining these materials. The most important ones include wetting of the ceramic material surface by liquid metal and mutual chemical interaction between the liquid metal and ceramic, related with diffusion processes. The reactivity and wetting behavior in a metal/ceramic system can in turn be improved, e.g., by applying thin metallic layers to the ceramic material surface (Ref 5, 6). Such layers can be reactive against the bonded materials so that a fixed bond on the phase boundaries is formed, creating diffusion, reactive intermediate microlayers in the most favorable case; the layers have a physical and chemical compatibility (thermodynamic and kinetic), which guarantees good mechanical characteristics of the joint. A number of studies focus on research of the influence between pure titanium and $\mathrm{Al}_{2} \mathrm{O}_{3}$ together with the definition of the morphology of the reaction area which is created at the interface of $\mathrm{Ti} / \mathrm{Al}_{2} \mathrm{O}_{3}$. Kelkar et al. in their study ( $\operatorname{Ref} 7$ ) on the basis of thermodynamic calculations present a concept that the influence between liquid $\mathrm{Al}$ and titanium covering $\mathrm{Al}_{2} \mathrm{O}_{3}$ in a vacuum, even at low partial pressures of oxygen, leads to changes in the chemical composition of the interface at the side of the substrate by forming the following reaction layer: $\mathrm{Al} / \mathrm{Al}_{2} \mathrm{O}_{3} / \mathrm{Tix} \mathrm{Oy} / \mathrm{Ti} / \mathrm{Ti} x \mathrm{Oy} / \mathrm{Al}_{2} \mathrm{O}_{3}$.

In the previous work ( $\operatorname{Ref} 8)$, experimental results revealed that the addition of $\mathrm{Ti}$ and $\mathrm{Nb}$ improves the wetting; titanium influences the contact angle more than niobium (probably because it has a higher chemical affinity to oxygen); and at a thin layer less than $1 \mu \mathrm{m}$, the minimal contact angle was reached $\left(40^{\circ}\right.$ for titanium and $108^{\circ}$ for niobium at $\left.1223 \mathrm{~K}\right)$.

The aim of this work was to study the effect of the $\mathrm{Ti}+\mathrm{Nb}$ thin film on alumina on the interface structure, bond strength 
properties at room and elevated temperatures, and the mechanism of destruction of $\mathrm{Al}_{2} \mathrm{O}_{3} / \mathrm{Al} / \mathrm{Al}_{2} \mathrm{O}_{3}$ joints.

\section{Experimental Procedure and Materials}

The $\mathrm{Al}_{2} \mathrm{O}_{3} / \mathrm{Al} / \mathrm{Al}_{2} \mathrm{O}_{3}$ joints were produced by liquid-state bonding of $98 \%$ pure polycrystalline $\mathrm{Al}_{2} \mathrm{O}_{3}$ blocks $(14 \times 14 \times 20 \mathrm{~mm})$ and $99.99 \%$ pure aluminum of $30 \mu \mathrm{m}$ thick layer.

Foils of the metal $(14 \times 14 \mathrm{~mm}$ dimensions $)$ were placed between the alumina blocks, and bonding was performed at $973 \mathrm{~K}$ with a vacuum of $0.2 \mathrm{mPa}$ for $5 \mathrm{~min}$. The heating and cooling rates used were 30 and $10 \mathrm{~min}$, respectively. The alumina blocks of $3.8 \mathrm{~g} / \mathrm{cm}^{3}$ (almost $0 \%$ porosity) were produced by sintering at the temperature of $1923 \mathrm{~K}$ for $2 \mathrm{~h}$; powders have the following starting composition: $99.9085 \% \alpha-\mathrm{Al}_{2} \mathrm{O}_{3}, 0.009 \% \mathrm{CaO}, 0.053 \%$ $\mathrm{SiO}_{2}, 0.0029 \% \mathrm{MgO}, 0.023 \% \mathrm{Fe}_{2} \mathrm{O}_{3}$, and $0.0036 \% \mathrm{Na}_{2} \mathrm{O}$. The polycrystalline alumina contained $2 \%$ of $\mathrm{Mg}\left(\mathrm{SiO}_{4}\right)$ and $\mathrm{MgAl}_{2} \mathrm{O}_{4}$ spinels. The Al foil was mechanically and ultrasonically cleaned in acetone, rinsed in alcohol for $10 \mathrm{~min}$, and then dried with warm air directly before bonding. The $\mathrm{Al}$ foils were positioned between two $\mathrm{Al}_{2} \mathrm{O}_{3}$ blocks, and this assembly was placed in a vacuum chamber under a load applied by placing one of the $\mathrm{Al}_{2} \mathrm{O}_{3}$ blocks on top of the assembly to maintain structural integrity during bonding.

The surfaces to be joined were lapped flat to a $1-\mu \mathrm{m}$ finish, ultrasonically cleaned in acetone, and finally a 900-nm-thin $\mathrm{Ti}+\mathrm{Nb}$ layer was deposited on the surface by physical vapor deposition (PVD). The film was deposited by rf sputtering of a mosaic $\mathrm{Ti}+\mathrm{Nb}$ target in argon gas atmosphere onto different substrates such as Corning glasses and alumina, depending on the requirements imposed by further applications, i.e., for the determination of the film thickness and composition. The film thickness was measured mechanically by means of a Tally Step profilometer. Research with the use of a scanning electron microscope revealed that the thin layer is smooth and nonporous and that it contains both $\mathrm{Ti}$ and $\mathrm{Nb}$. The thin film composition was determined from X-ray diffraction (XRD). The weight ratio $\mathrm{Nb} /(\mathrm{Nb}+\mathrm{Ti})$ was found to be equal to 0.625 (62.5 wt.\%).

After bonding, the joints were tested at 295, 373, and $473 \mathrm{~K}$, using the four-point bending test with an inner span of 12.5 and outer span of $25 \mathrm{~mm}$. Specimens of dimensions $3 \times 3 \times 36 \mathrm{~mm}^{3}$ for the four-point bend testing were cut from one bonded sample. The specimens were tested using an INSTRON 1115 machine with the automatic recording of the applied load versus the corresponding displacement up to failure under a constant load displacement rate of $1 \mathrm{~mm} / \mathrm{min}$. The reported results are averages of between three and five tests that were run for each condition. The impact of temperature was analyzed within the range of $295-473 \mathrm{~K}$ on the course of joint's bending characteristics, due to the fact that in practice deformation at a temperature (above 0.25 of melting point) is used to minimize the deformation resistance and increase the plasticity of brittle materials.

The structure was examined on sandwich specimens after joining, using optical microscopy (LM), scanning electron microscopy (SEM), and transmission electron microscopy (TEM). LM/ SEM studies were performed on fractured joint specimens, cross sectioned in a plane inclined at about $25^{\circ}$ to the joint surface (to enable the enlargement of the joint area available for examinations; it is noted that this technique lowers somewhat the spatial resolution of EDS composition line scans). Moreover, SEM/EDS studies were performed to study failure characteristics of fractured joint surfaces.
The specimens for TEM examination (Model PHILIPS CM20 TWIN operated at $200 \mathrm{KV}$ ) were prepared using a method for the preparation of coated material by sandwiching described in detail in (Ref 9) (comprising specimen prepreparation, bonding together by epoxy glue, mounting, mechanical pre-thinning, and thinning by ion-beam milling until perforation).

\section{Results and Discussion}

The four-point bending test results of the ceramic-metalceramic joints bonded at $973 \mathrm{~K}$ are summarized in Fig. 1 for $\mathrm{Al}_{2} \mathrm{O}_{3} / \mathrm{Al} / \mathrm{Al}_{2} \mathrm{O}_{3}$ and $\mathrm{Al}_{2} \mathrm{O}_{3} / \mathrm{Ti}+\mathrm{Nb} / \mathrm{Al} / \mathrm{Ti} /+\mathrm{Nb} / \mathrm{Al}_{2} \mathrm{O}_{3}$ joints, where the bending strengths are reported at $295,373,473 \mathrm{~K}$. Together with the increase of temperature, the force parameters of the bending process decrease and increase the values of bend arrows in the samples, whereas a change in temperature from 295 to 373 and $473 \mathrm{~K}$ for sample types $\mathrm{Al}_{2} \mathrm{O}_{3} / \mathrm{Al} / / \mathrm{Al}_{2} \mathrm{O}_{3}$ causes a dramatic change both in stress and in the shape of the bending curve. Maximum bending stress at $T=473 \mathrm{~K}$ decreases twofold, while $\mathrm{Al}_{2} \mathrm{O}_{3} / \mathrm{Ti}+\mathrm{Nb} / \mathrm{Al} / \mathrm{Ti}+\mathrm{Nb} / \mathrm{Al}_{2} \mathrm{O}_{3}$ joints in the tested temperature range maintain the same character of the bending curve, which in turn proves the same character of the deformation mechanism at the room temperature and elevated temperature. Specimens of types $\mathrm{Al}_{2} \mathrm{O}_{3} / \mathrm{Al} / / \mathrm{Al}_{2} \mathrm{O}_{3}$ and $\mathrm{Al}_{2} \mathrm{O}_{3} / \mathrm{Ti}+\mathrm{Nb} / \mathrm{Al} /$ $\mathrm{Ti}+\mathrm{Nb} / \mathrm{Al}_{2} \mathrm{O}_{3}$ at $295 \mathrm{~K}$ displayed an average breaking stress with a standard deviation of about $10 \mathrm{MPa}$, while specimens of the same type at 373 and $473 \mathrm{~K}$ had a standard deviation of about $15 \mathrm{MPa}$. At $295 \mathrm{~K}$, the standard deviation was smaller, and its value increased together with the increase of temperature during the examination. The increase of the standard deviation may indicate a more complex character of damaging the sample, which by nature influences more extended distribution of strength tests. It has been shown that the bending strengths of metal-ceramic joints with $\mathrm{Ti}+\mathrm{Nb}$ coating have been improved compared to those joints without coatings at elevated temperature. Furthermore, it was found that $\mathrm{Al}_{2} \mathrm{O}_{3} / \mathrm{Ti}+\mathrm{Nb} / \mathrm{Al} / \mathrm{Ti}+\mathrm{Nb} / \mathrm{Al}_{2} \mathrm{O}_{3}$ joints retained its strength to higher temperatures. The bending strength of $\mathrm{Al}_{2} \mathrm{O}_{3}$ / $\mathrm{Al} / \mathrm{Al}_{2} \mathrm{O}_{3}$ was about $158 \pm 15$ and $125 \pm 15 \mathrm{MPa}$, while the strength of $\mathrm{Al}_{2} \mathrm{O}_{3} / \mathrm{Ti}+\mathrm{Nb} / \mathrm{Al} / \mathrm{Ti} /+\mathrm{Nb} / \mathrm{Al}_{2} \mathrm{O}_{3}$ was $185 \pm 15$ and $158 \pm 15 \mathrm{MPa}$ at 373 and $473 \mathrm{~K}$, respectively. On the other hand, the bending strength of $\mathrm{Al}_{2} \mathrm{O}_{3} / \mathrm{Ti}+\mathrm{Nb} / \mathrm{Al} / \mathrm{Ti}+\mathrm{Nb} / \mathrm{Al}_{2} \mathrm{O}_{3}$ joint is much lower than $\mathrm{Al}_{2} \mathrm{O}_{3} / \mathrm{Al} / \mathrm{Al}_{2} \mathrm{O}_{3}$ joint, wherein the bending curve has better plasticity behavior at $295 \mathrm{~K}$. The prime role of such plasticity is to accommodate the mismatched thermal contractions of the $\mathrm{Al}_{2} \mathrm{O}_{3}$ and metal.

The significant increase in the bend stress of $\mathrm{Al}_{2} \mathrm{O}_{3} / \mathrm{Ti}+\mathrm{Nb} /$ $\mathrm{Al} / \mathrm{Ti}+\mathrm{Nb} / \mathrm{Al}_{2} \mathrm{O}_{3}$ joint compared to the values of $\mathrm{Al}_{2} \mathrm{O}_{3} / \mathrm{Al} /$ $\mathrm{Al}_{2} \mathrm{O}_{3}$ joint at elevated temperatures may be the result of changes in chemistry of the region of interface, which lead to generating a favorable gradient structure type $\mathrm{Al}(\mathrm{Nb}, \mathrm{Ti})+\mathrm{Al}_{3}(\mathrm{Nb}, \mathrm{Ti}) / \mathrm{Al}_{2} \mathrm{O}_{3}$ and thus lead to increased strength, and in the interaction between interfacial precipitates and dislocations during deformation at the bonding interface which causes the higher yield strength. Such interfacial structure in $\mathrm{Al}_{2} \mathrm{O}_{3} / \mathrm{Ti}+\mathrm{Nb} / \mathrm{Al} / \mathrm{Ti}+\mathrm{Nb} / \mathrm{Al}_{2} \mathrm{O}_{3}$ joint provides a gradual transition in physical properties and help minimize the effect of local stresses that develop from the mismatch between the coefficient of thermal expansion of $\mathrm{Al}_{2} \mathrm{O}_{3}$ and the bonding layer of $\mathrm{Al}$ (containing $\mathrm{Nb}$ and $\mathrm{Ti}$ ).

The fracture modes of the $\mathrm{Al}_{2} \mathrm{O}_{3} / \mathrm{Ti}+\mathrm{Nb} / \mathrm{Al} / \mathrm{Ti}+\mathrm{Nb} / \mathrm{Al}_{2} \mathrm{O}_{3}$ joints also differ from that of $\mathrm{Al}_{2} \mathrm{O}_{3} / \mathrm{Al} / \mathrm{Al}_{2} \mathrm{O}_{3}$. Figure 2 presents 

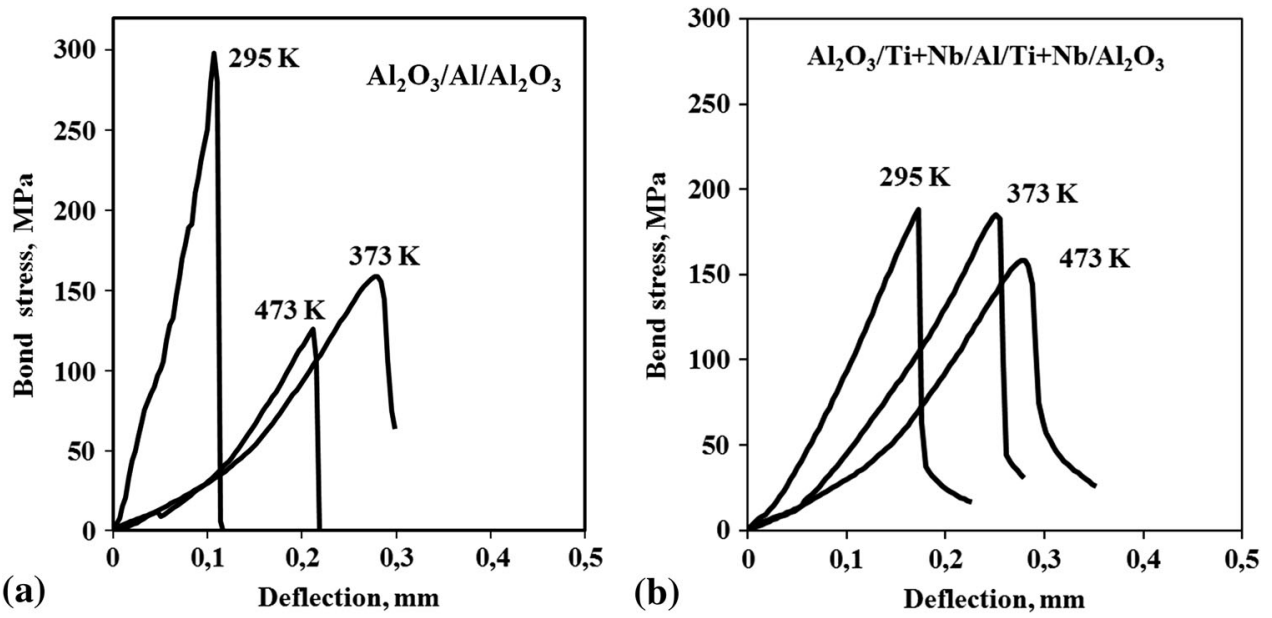

Fig. 1 Bend test curves recorded for (a) $\mathrm{Al}_{2} \mathrm{O}_{3} / \mathrm{Al} / \mathrm{Al}_{2} \mathrm{O}_{3}$ and (b) $\mathrm{Al}_{2} \mathrm{O}_{3} / \mathrm{Ti}+\mathrm{Nb} / \mathrm{Al} / \mathrm{Ti}+\mathrm{Nb} / \mathrm{Al}_{2} \mathrm{O}_{3}$ joints at 295, 373, and $473 \mathrm{~K}$
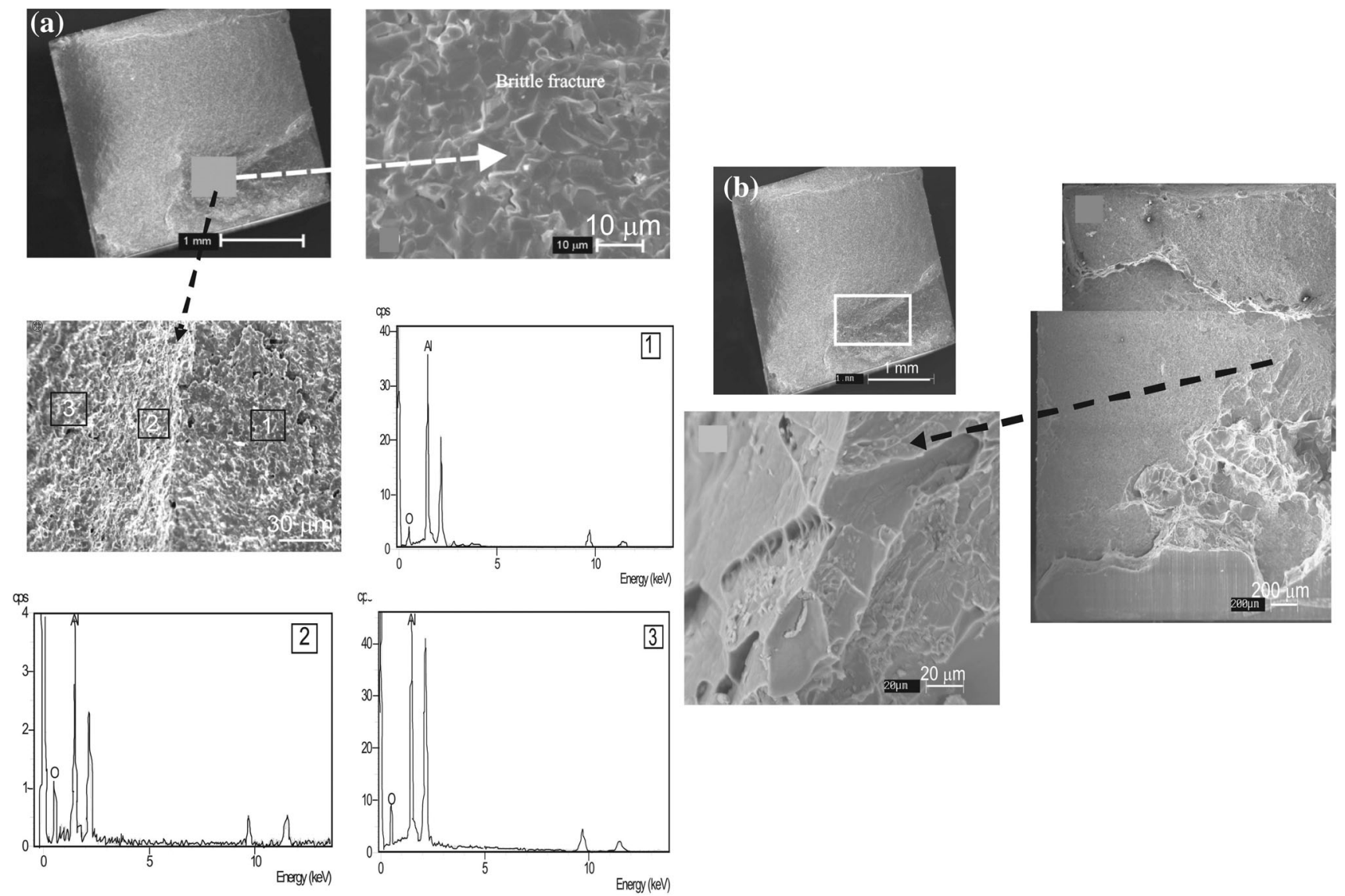

Fig. 2 SEM micrographs of fracture surface after bend test at $295 \mathrm{~K}$ (a) of $\mathrm{Al}_{2} \mathrm{O}_{3} / \mathrm{Al} / \mathrm{Al}_{2} \mathrm{O}_{3}$ joint with corresponding EDS spectrum taken from the marked points 1,2 , and 3 , and (b) of $\mathrm{Al}_{2} \mathrm{O}_{3} / \mathrm{Ti}+\mathrm{Nb} / \mathrm{Al} / \mathrm{Ti}+\mathrm{Nb} / \mathrm{Al}_{2} \mathrm{O}_{3}$ joint

images of the fracture surfaces resulting from the bending test at 295 K. As illustrated in Fig. 2, two types of fracture modes exist in the ceramic-to metal joints without and with $\mathrm{Ti}+\mathrm{Nb}$ coating. In type $\mathrm{I}$, the crack exists in the ceramic during initiating and propagating periods. In joints $\mathrm{Al}_{2} \mathrm{O}_{3} / \mathrm{Al} / \mathrm{Al}_{2} \mathrm{O}_{3}$, brittle fractures occur along the cleavage planes of the $\mathrm{Al}_{2} \mathrm{O}_{3}$ phase. This indicates that the bonding strength of $\mathrm{Al} / \mathrm{Al}_{2} \mathrm{O}_{3}$ interface is higher than that of the $\mathrm{Al}_{2} \mathrm{O}_{3}$. The region of $\mathrm{Al} / \mathrm{Al}_{2} \mathrm{O}_{3}$ interface is "clean" without segregants and reaction products; they tend to be detrimental as it can form brittle compounds. In type II (for the $\mathrm{Al}_{2} \mathrm{O}_{3} / \mathrm{Ti}+\mathrm{Nb} / \mathrm{Al} / \mathrm{Ti}+\mathrm{Nb} / \mathrm{Al}_{2} \mathrm{O}_{3}$ joints) cracking occurs both in the metal near the interface and along the interface, which suggests that this region represents the combination of the solid solution and precipitation strengthening (associated with the presence of intermetallics and of Al-rich solid solution, resulting from dissolution of coatings). 


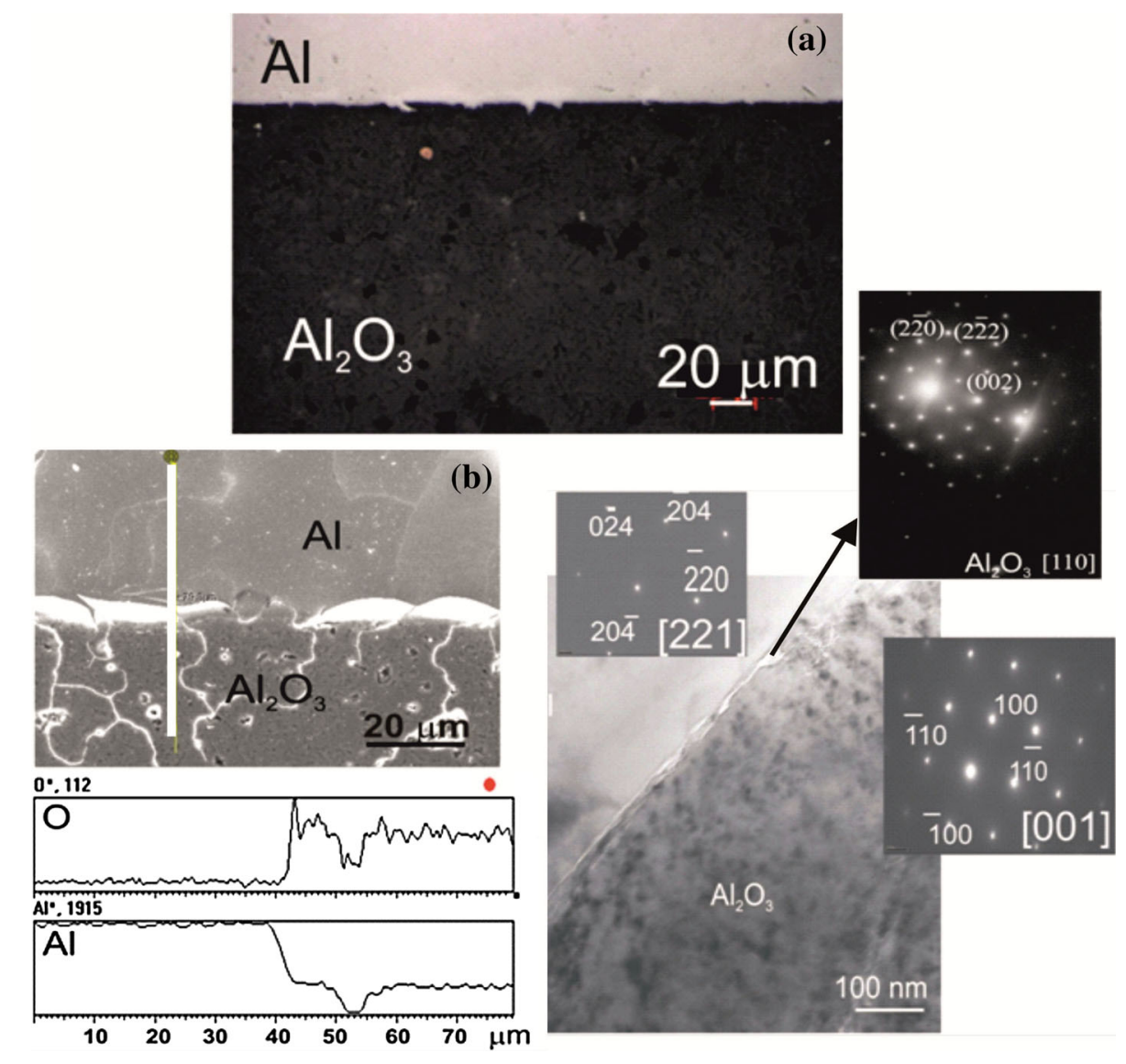

(a)

Fig. 3 Structural examination of the $\mathrm{Al}_{2} \mathrm{O}_{3} / \mathrm{Al} / \mathrm{Al}_{2} \mathrm{O}_{3}$ joint: (a) optical micrograph, (b) SEM analysis of the interface: distribution of $\mathrm{O}$ and $\mathrm{Al}$ along white line marked in (b), (c) TEM analysis of the interface with representative selected area diffraction patterns indicates the $\mathrm{Al}$ and $\mathrm{Al}_{2} \mathrm{O}_{3}$ phases

For the explanation of the mechanism controlling the bonding process in $\mathrm{Al}_{2} \mathrm{O}_{3} / \mathrm{Ti}+\mathrm{Nb} / \mathrm{Al} / \mathrm{Ti}+\mathrm{Nb} / \mathrm{Al}_{2} \mathrm{O}_{3}$ joints, the structural examinations were carried out in the region of $\mathrm{Al} /$ $\mathrm{Ti}+\mathrm{Nb} / \mathrm{Al}_{2} \mathrm{O}_{3}$ bond by the method of optical microscopy, combined with SEM and TEM, shown in Fig. 3 and 4.

The bonding between $\mathrm{Al}_{2} \mathrm{O}_{3}$ and $\mathrm{Al}$ layer was achieved by growing the $\mathrm{Al}_{2} \mathrm{O}_{3}$ phase at the interface. The presence of isolated separate particles of $\mathrm{Al}_{2} \mathrm{O}_{3}$ was confirmed experimentally by $\mathrm{SEM} / \mathrm{TEM}$ studies in the region of the interface in $\mathrm{Al}_{2} \mathrm{O}_{3} / \mathrm{Al} / \mathrm{Al}_{2} \mathrm{O}_{3}$ joint (Fig. 3). SEM analysis of the fracture surface of this joint (Fig. 2a) also confirms the presence of $\mathrm{Al}_{2} \mathrm{O}_{3}$ phases at the interface. It is obvious that oxygen plays an important role in improving the bond strength between $\mathrm{Al}$ and $\mathrm{Al}_{2} \mathrm{O}_{3}$, probably because of the formation of metal clusters (Ref 10) and chemical interaction between liquid $\mathrm{Al}$ and additives in ceramic (Ref 11). At a temperature below $1373 \mathrm{~K}$, through a reduction reaction of silico-aluminate spinels by liquid $\mathrm{Al}$, it is possible to form $\mathrm{Al}_{2} \mathrm{O}_{3}$ precipitates at the interface, which in turn is conducive to reinforcement of the interface. Therefore, the microstructure of the joint shows a strong bonding at the interfaces. Bend testing at $295 \mathrm{~K}$ showed that fractures always occurred within the ceramic material.

Observations of the $\mathrm{Al} / \mathrm{Ti}+\mathrm{Nb} / \mathrm{Al}_{2} \mathrm{O}_{3}$ system interface under a magnification of $500 \times$ revealed the presence of interfacial precipitates, along the interface (Fig. 4). SEM observations
(Fig. 4b) have proved the formation of new phases, i.e., a phase containing mainly $\mathrm{Nb}$ and $\mathrm{Ti}$. The local analysis of the chemical composition of the above-mentioned precipitates has indicated that these are the precipitates of intermetallic phases rich in $\mathrm{Nb}$ and $\mathrm{Ti}$ (e.g., items 1, 2, and 3 in Fig. 4b, respectively). The chemical composition in the interface region also shows maps of the distribution of the elements like aluminum, titanium, and niobium (Fig. 4b).

Moreover, the last statement was confirmed experimentally by TEM studies of the $\mathrm{Al} / \mathrm{Ti}+\mathrm{Nb} / \mathrm{Al}_{2} \mathrm{O}_{3}$ system interface and the presence of particles of $\mathrm{Al}_{3} \mathrm{Nb}$ (Ti) in the region of interface (Fig. 4c). The structural analysis of the $\mathrm{Al} / \mathrm{Ti}+\mathrm{Nb} / \mathrm{Al}_{2} \mathrm{O}_{3}$ bond interfaces produced in the joining process at $973 \mathrm{~K}$ indicates that the joining effect has been accompanied by intense chemical interaction between the $\mathrm{Ti}+\mathrm{Nb}$ film-coated substrate and liquid aluminum. The mechanism of this interaction is probably solutionprecipitation based and is related to the dissolution of $\mathrm{Ti}+\mathrm{Nb}$ coating in liquid aluminum and the formation of a solid solution $\mathrm{Al}(\mathrm{Nb}, \mathrm{Ti})$ in the contact region during the process of bonding. However, the precipitates of phases rich in $\mathrm{Nb}$ and Ti nucleate at the distance of approx. $5 \mu \mathrm{m}$ from the interface from the supersaturated $\mathrm{Al}(\mathrm{Nb}, \mathrm{Ti})$ solution, during the cooling of the joint to the ambient temperature (Ref 12).

Figure 5 illustrates the fracture surface of $\mathrm{Al}_{2} \mathrm{O}_{3} / \mathrm{Ti}+\mathrm{Nb} /$ $\mathrm{Al} / \mathrm{Ti}+\mathrm{Nb} / \mathrm{Al}_{2} \mathrm{O}_{3}$ joints after bending test at elevated 
(a)

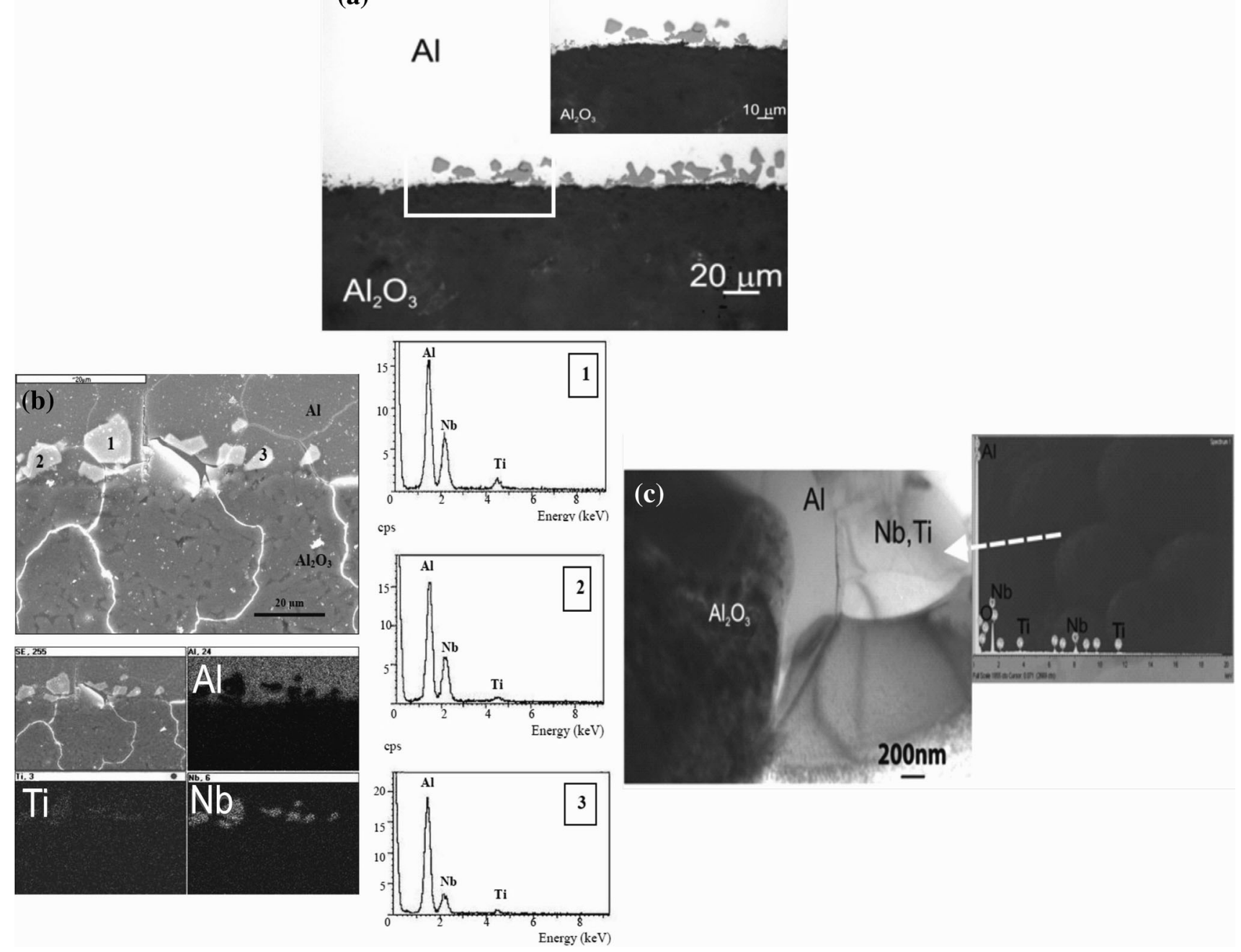

Fig. 4 Structural examination of the $\mathrm{Al}_{2} \mathrm{O}_{3} / \mathrm{Ti}+\mathrm{Nb} / \mathrm{Al} / \mathrm{Ti}+\mathrm{Nb} / \mathrm{Al}_{2} \mathrm{O}_{3}$ joint: (a) optical micrograph showing the reaction layer in the interfacial region, (b) SEM analysis of the interface with corresponding EDS spectrum taken from the marked points 1, 2, 3, and titanium, aluminum, and niobium X-ray maps and (c) TEM analysis of the interface showing a new phase containing $\mathrm{Nb}$ and $\mathrm{Ti}$

temperatures. According to this figure, the fracture preceded in the metal layer near the metal-ceramic interface by ductile rupture mechanism. In the fracture surface, the conventional ductile fracture process generated the regions with dimples. The dimples are believed to initiate at the precipitates of intermetallic phases rich in $\mathrm{Nb}$ and $\mathrm{Ti}$ (e.g., items 1 and 2 in Fig. 5a). Finally, interfacial precipitates of intermetallic phases can both embrittle the region of the $\mathrm{Al}_{2} \mathrm{O}_{3} / \mathrm{Ti}+\mathrm{Nb} / \mathrm{Al}$ interface and plastically blunt and eliminate high stress concentrations. In the fracture surface obtained after bending test at $473 \mathrm{~K}$, more dimples which are shallower and bigger than the dimples in the fracture surface after bending test at $373 \mathrm{~K}$ are observed. These fracture types observed in the $\mathrm{Al}_{2} \mathrm{O}_{3} / \mathrm{Al} / \mathrm{Al}_{2} \mathrm{O}_{3}$ and $\mathrm{Al}_{2} \mathrm{O}_{3} /$ $\mathrm{Ti}+\mathrm{Nb} / \mathrm{Al} / \mathrm{Ti}+\mathrm{Nb} / \mathrm{Al}_{2} \mathrm{O}_{3}$ joints correspond with the bending strength results shown in Fig. 1, where the $\mathrm{Al}_{2} \mathrm{O}_{3} / \mathrm{Ti}+\mathrm{Nb} / \mathrm{Al} /$ $\mathrm{Ti}+\mathrm{Nb} / \mathrm{Al}_{2} \mathrm{O}_{3}$ joints generally have higher strength than $\mathrm{Al}_{2} \mathrm{O}_{3} / \mathrm{Al} / \mathrm{Al}_{2} \mathrm{O}_{3}$ joints at elevated temperatures. Structural examinations revealed that effective reinforcement of the interfacial region of $\mathrm{Al}_{2} \mathrm{O}_{3} / \mathrm{Ti}+\mathrm{Nb} / \mathrm{Al} / \mathrm{Ti}+\mathrm{Nb} / \mathrm{Al}_{2} \mathrm{O}_{3}$ joint, which consists of hard-and brittle-phase precipitates rich in $\mathrm{Nb}$ and $\mathrm{Ti}$ in a solid $\mathrm{Al}(\mathrm{Nb}, \mathrm{Ti})$ solution with optimal plasticity, contributes to increased mechanical strength at elevated temperatures.

\section{Summary and Conclusion}

The effect of a thin film $\mathrm{Ti}+\mathrm{Nb}$ interlayer on the microstructure and strength of $\mathrm{Al}_{2} \mathrm{O}_{3} / \mathrm{Al} / \mathrm{Al}_{2} \mathrm{O}_{3}$ joints at elevated temperatures is determined by the four-point bend testing, SEM, and TEM analyses.

The following conclusions were drawn:

- Better quality of $\mathrm{Al}_{2} \mathrm{O}_{3} / \mathrm{Ti}+\mathrm{Nb} / \mathrm{Al} / \mathrm{T}+\mathrm{Nb} / \mathrm{Al}_{2} \mathrm{O}_{3}$ joints at elevated temperatures relative to $\mathrm{Al}_{2} \mathrm{O}_{3} / \mathrm{Al} / \mathrm{Al}_{2} \mathrm{O}_{3}$ joints is due to specific interfacial microstructure (resulting in a solution and precipitation of rich $\mathrm{Nb}$ and $\mathrm{Ti}$ intermetallic phases) combined with plastic deformation on the metal side during fracture and leads to the production of reliable metal/ceramic joints

- Fractography of $\mathrm{Al}_{2} \mathrm{O}_{3} / \mathrm{Al} / \mathrm{Al}_{2} \mathrm{O}_{3}$ and $\mathrm{Al}_{2} \mathrm{O}_{3} / \mathrm{Ti}+\mathrm{Nb} / \mathrm{Al} /$ $\mathrm{Ti}+\mathrm{Nb} / \mathrm{Al}_{2} \mathrm{O}_{3}$ joints at elevated temperatures showed that 

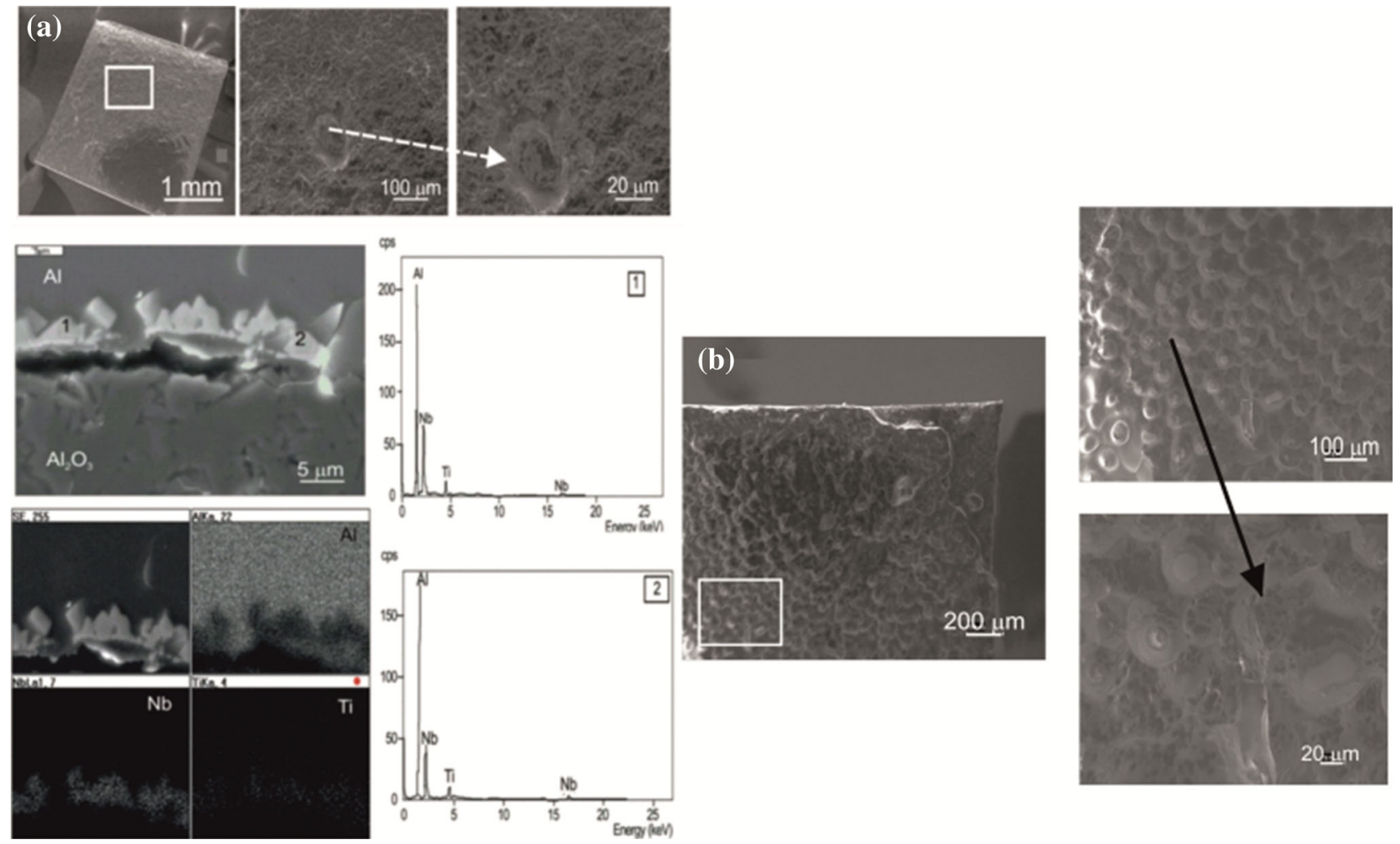

Fig. $5 \mathrm{SEM}$ micrographs of fracture surface of $\mathrm{Al}_{2} \mathrm{O}_{3} / \mathrm{Ti}+\mathrm{Nb} / \mathrm{Al} / \mathrm{Ti}+\mathrm{Nb} / \mathrm{Al}_{2} \mathrm{O}_{3}$ joints after bend test (a) at $373 \mathrm{~K}$ using $\mathrm{SEM}$ analysis of the interface with the corresponding EDS spectrum taken from the marked points 1,2, and titanium, aluminum, and niobium X-ray maps, and (b) at $473 \mathrm{~K}$

failure occurred by plastic cracking in the metal near the interface. The only possible exception is $\mathrm{Al}_{2} \mathrm{O}_{3} / \mathrm{Al} / \mathrm{Al}_{2} \mathrm{O}_{3}$ joint at $295 \mathrm{~K}$, which appears to be always caused by brittle fracture of the $\mathrm{Al}_{2} \mathrm{O}_{3}$.

\section{Acknowledgments}

This work was supported by the Ministry of Science and Higher Education under the Project No. 3T08B047 30

\section{Open Access}

This article is distributed under the terms of the Creative Commons Attribution License which permits any use, distribution, and reproduction in any medium, provided the original author(s) and the source are credited.

\section{References}

1. G. Cam and M. Kocak, Progress in Joining of Advanced Metals, Int. Mater. Rev., 1998, 43(1), p 1-39

2. S.B. Sinnott and E.C. Dickey, Ceramic/Metal Interface Structures and Their Relationship to Atomic- and Meso-Scale Properties, Mater. Sci. Eng., 2003, 43(1-2), p 1-59
3. J.H. Selverin, F.S. Ohuchi, M. Bortz, and M.R. Notis, Interface Reactions Between Titanium Thin Films and (112) Sapphire Substrate, J. Mater. Sci., 1991, 26, p 6300-6308

4. A.K. Jadan, B. Ralph, and P.R. Hornsby, Metal to Ceramic Joining via a Metallic Interlayer Bonding Technique, J. Mater. Process. Technol., 2004, 152, p 257-265

5. M.L. Hattali, S. Valette, F. Ropital, N. Mesrati, and D. Treheux, Effect of Thermal Residual Stresses on the Strength for Both Alumina/Ni/ Alumina and Alumina/Ni/Nickel Alloy Biomaterials, J. Mater. Sci., 2009, 44, p 3198-3210

6. S.M. Hong, T.B. Reynolds, C.C. Bartlow, and A.M. Glaser, Rapid Transient-Liquid-Phase Bonding of $\mathrm{Al}_{2} \mathrm{O}_{3}$ with Microdesigned $\mathrm{Ni} / \mathrm{Nb} /$ Ni Interlayers, Int. J. Mater. Res., 2010, 101(1), p 133-142

7. G.P. Kelkar and A.H. Carim, Phase Equilibria in the Ti-Al-O System at $945{ }^{\circ} \mathrm{C}$ and Analysis of $\mathrm{Ti} / \mathrm{Al}_{2} \mathrm{O}_{3}$ Reactions, J. Am. Ceram. Soc., 1995, 78(3), p 572-576

8. M. Ksiazek, M. Richert, A. Tchorz, and L. Boron, Effect of Ti, Nb, and $\mathrm{Ti}+\mathrm{Nb}$ Coatings on the Bond Strength-Structure Relationship in $\mathrm{Al} /$ $\mathrm{Al}_{2} \mathrm{O}_{3}$ Joints, J. Mater. Eng. Perform., 2012, 21(5), p 690-695

9. A. Strecker, U. Salzberger, and J. Mayer, Specimen Preparation for Transmission Electron Microscopy: Reliable Methods for CrossSections and Brittle Materials, Prakt. Metalogr., 1993, 30, p 482-495

10. P. Kritsalis, V. Merlin, L. Coudurier, and N. Eustathopoulos, Effect of $\mathrm{Cr}$ on Interfacial Interaction and Wetting Mechanism in Ni Alloy/ Alumina Systems, Acta Metall. Mater., 1992, 40(6), p 1167-1174

11. Ch Leinenbach, N. Werich, H.-R. Elsner, and G. Gamez, $\mathrm{Al}_{2} \mathrm{O}_{3}-\mathrm{Al}_{2} \mathrm{O}_{3}$ and $\mathrm{Al}_{2} \mathrm{O}_{3}$-Ti-Solder Joints-Influence of Ceramic Metallization and Thermal Pretreatment on Joint Properties, Int. J. Appl. Ceram. Technol., 2012, 9(4), p 751-763

12. V. Raghavan, Al-Nb-Ti (Aluminium-Niobium-Titanium), J. Phase Equilib. Diffus., 2005, 26(4), p 360-368 